\title{
Interannual variability of dense shelf water salinities in the north-western Barents Sea \\ Sönke Maus

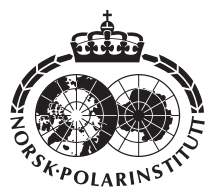

The maximum dense shelf water salinity formed during winter in the Svalbard Bank area of the north-western Barents Sea is reconstructed for the period 1952-2000 by analysing the transformation of summer remnants. The variability of 34.7-35.4, waters being at the freezing point, is mainly generated by interannual variations in the near surface salinity. On interannual time scales the latter is strongly linked to the sea ice import. In contrast, no correlation of the salinity of the Atlantic Water (AW) throughflow to the Arctic Ocean with the ice import is found. Salinities of both the dense shelf water site in the north-west Barents Sea and the north-eastward AW throughflow show a long term decrease, which can partly be explained by a less saline inflow of AW from the Norwegian Sea. The unusually low dense water salinities in the north-west Barents Sea during the 1990s appear to have a different origin, consistent with a response to oceanic heat advection and decreasing sea ice extent.

Sönke Maus, Institute of Oceanography Hamburg, Troplowitzstrasse 7, D-22529 Hamburg, Germany.

The processes of deep water formation in the Nordic seas must be understood to analyse polar and global climate variability. Long-term changes in the deep water properties of the Greenland, Iceland and Norwegian (GIN) seas are documented for the past decades (Østerhus \& Gammelsrød 1999; Alekseev et al. 2001) and have been associated with a reduction of open ocean deep water formation in the Greenland Sea during the 1980s and 1990s. One important suggested cause is the upper layer freshening of the GIN Sea (Blindheim et al. 2000; Alekseev et al. 2001). The consequences of this hydrographic change for convective flows emerging from the shallow Barents Sea, as brine-enriched cold shelf waters, have not been documented yet. These flows are also relevant ventilation sources of Arctic Ocean and GIN Sea intermediate and deep waters (Midttun 1985; Anderson et al. 1999; Goldner 1999). The main reason for the lack of long interannual time series of dense shelf water properties is the restriction of most shipborne measurements to the summer season, when dense shelf waters have normally left the highly localized formation regi- ons. This study interprets summer remnants of cold saline winter waters within several reservoirs of the Svalbard Bank area in the north-west Barents Sea (Fig. 1) to analyse the interannual variability in the intensity of shelf convection. On the basis of summer data from 1950-2000, a time series of shelf convection maximum salinity is reconstructed. This maximum salinity can be viewed as a proxy for the winter shelf convection, as the dense bottom plume during the winter is rather persistent (Schauer \& Fahrbach 1999). As possible causes of its interannual variability I evaluate the variability of local ice formation, of the near surface salinity in the north-west Barents Sea and of ice advection from the Arctic Ocean. Results are compared to salinity series across the Barents Sea which resemble the throughflow of Atlantic Water (AW) to the Arctic Ocean.

From the BarKode database (Golubev \& Zuyev 1999) ca. 110000 hydrographic salinity profiles east of $5^{\circ} \mathrm{E}$ (Fig. 1) were retained after removing duplicates. This data set was enhanced by 43000 profiles from the period 1950-2000 provided by the Institute of Marine Research in Bergen and 


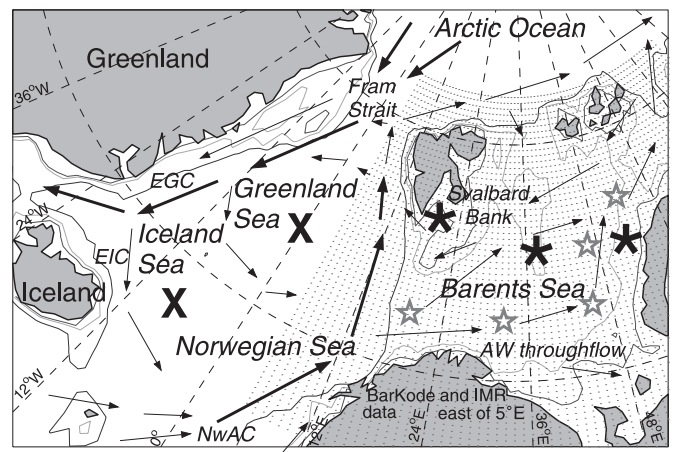

Fig. 1. Basic surface currents and convection areas of the Greenland, Iceland, Norwegian and Barents seas. X symbols mark open ocean, asterisks are shelf convection sites, stars indicate the Atlantic Water (AW) throughflow to the Arctic Ocean. EIC marks the location of the East Icelandic Current; NwAC is the Norwegian Atlantic Current. The depth contours are 100,200 and $500 \mathrm{~m}$.

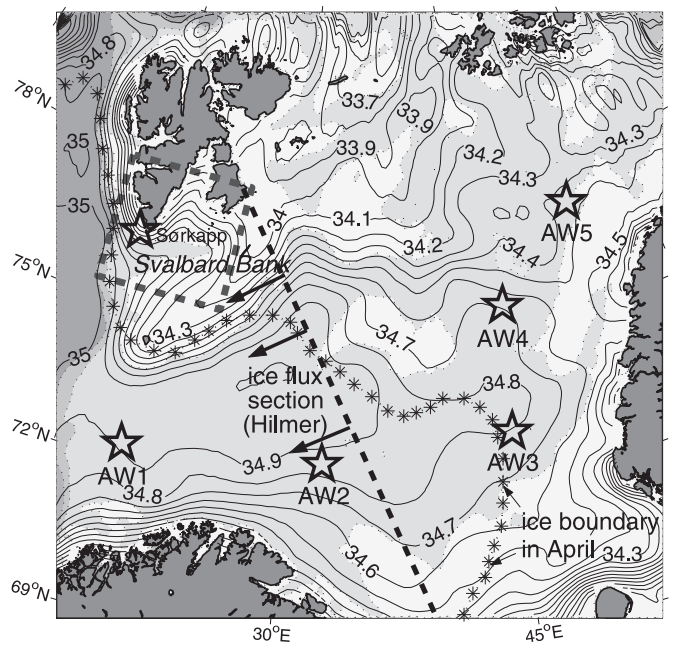

Fig. 2. Climatological September upper $(0-50 \mathrm{~m})$ salinity in the Barents Sea. Contour interval 0.1. Depth ranges (200, $500,1000 \mathrm{~m})$ are shaded; asterisks denote the typical April ice boundary; the straightt dashed line shows the ice export section from Hilmer (2001).

about 3000 profiles from the Variability and Exchange in the Nordic Seas programme and the initial phase of the Norwegian Ocean Climate programme. All profiles were linearly interpolated to $5 \mathrm{~m}$ levels. Then, on a $25 \mathrm{~km}$ polar stereographic grid, annual summer (August-October) averages were computed, after the annual cycle at each grid point, and depth was removed. Grid averaging was done by radially weighting anomalies within a distance of $30 \mathrm{~km}$ to maximally

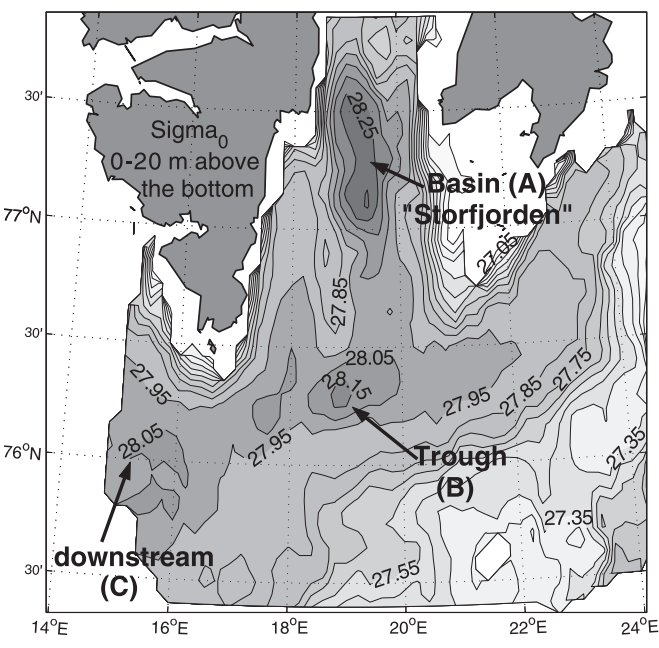

Fig. 3. Climatology of density averaged $20 \mathrm{~m}$ above the bottom based on observations June-October 1950-2000.

$60 \mathrm{~km}$, with respect to a finer $6.25 \mathrm{~km}$ climatology. The chosen spatial resolution yields $30-45$ years of data (within the time span 1950-2000) for most grid cells, reducing to 10-20 in the very northern and eastern Barents Sea. Profiles from reservoirs within the Svalbard Bank area are investigated individually.

The average upper layer salinity $(0-50 \mathrm{~m})$ in the Barents Sea derived for September is shown in Fig. 2. Polar Water (PW) north of the Polar Front is typically separated from AW by the 34.7-34.8 isohaline (Loeng 1991), which resembles the shown average sea ice boundary in April. In Storfjorden on the northern Svalbard Bank (site A in Figs. 3, 4) conditions favour the formation of brine-enriched dense shelf water. It is shallow and PW is near the freezing point throughout winter. Persistent offshore winds enhance the south-westerly ice export, creating high local ice production and brine release. The canyonlike bathymetry (Fig. 4) is well suited to guide the dense waters to the nearby deep sea slope west of Svalbard, whence they may sink to $2000 \mathrm{~m}$ depth (Quadfasel et al. 1988).

Several authors (Midttun 1985; Quadfasel et al. 1988; Maus 1995; Haarpaintner et al. 2001), have documented summer remnants of saline shelf waters close to the freezing point in Storfjorden, the bottom salinity varying interannually from 34.85 to 35.5 . Schauer (1995) showed that the maximum mooring salinity within the dense bottom flow, $50 \mathrm{~km}$ south of site A, was 35.13

Interannual variability of dense shelf water salinities 

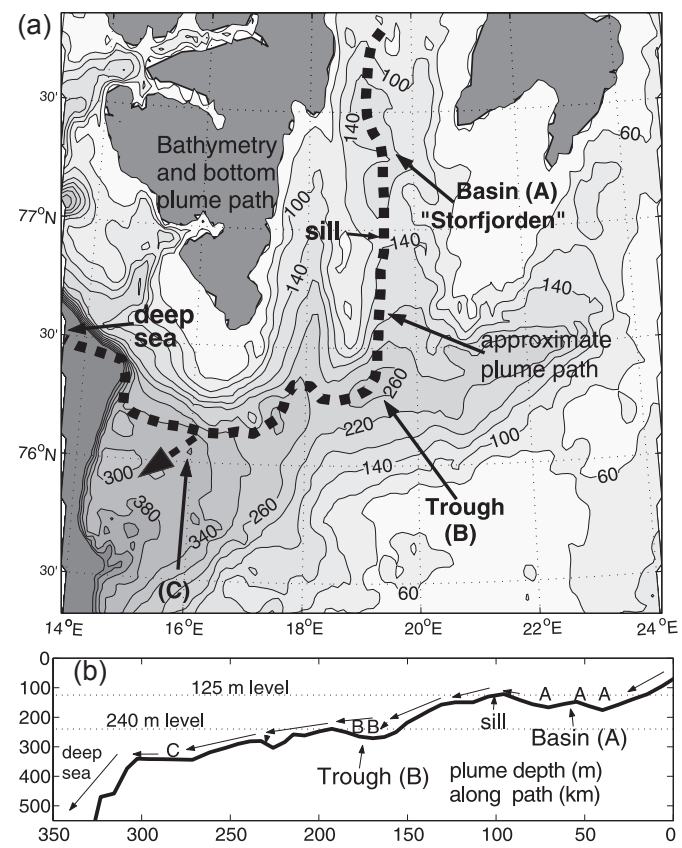

Fig. 4. (a) Bathymetry south of Svalbard with observation sites $\mathrm{A}$ and $\mathrm{B}$. The typical path of the dense water is indicated. (b) Depth along the plume's sinking path

for the winter 1991/92; it was 0.25 lower during 1993/94 (Schauer \& Fahrbach 1999).

To understand the interannual variability of 34.85-35.5 we need to know the relative importance of local ice production and hydrographic conditions south and east of Svalbard. Schauer \& Fahrbach (1999) attributed the different maximum salinities from two winters partly to the variable local polynya ice production, partly to different surface salinities in the previous autumn, but the ice maps used were rather coarse. Haarpaintner et al. (2001) failed to relate the difference between two winters to modelled ice production and instead suggested the polynya location in shallower waters as a possible cause. However, based on SSM/I data, Maus \& Bennet (2002) computed winter ice productions twice as large as Haarpaintner et al. (2001). The long time series to be derived may help to reduce apparent uncertainties in polynya ice modelling.

\section{Dense shelf water path and evolution}

The approximate path of dense shelf water from the reservoir to the slope has been indicated
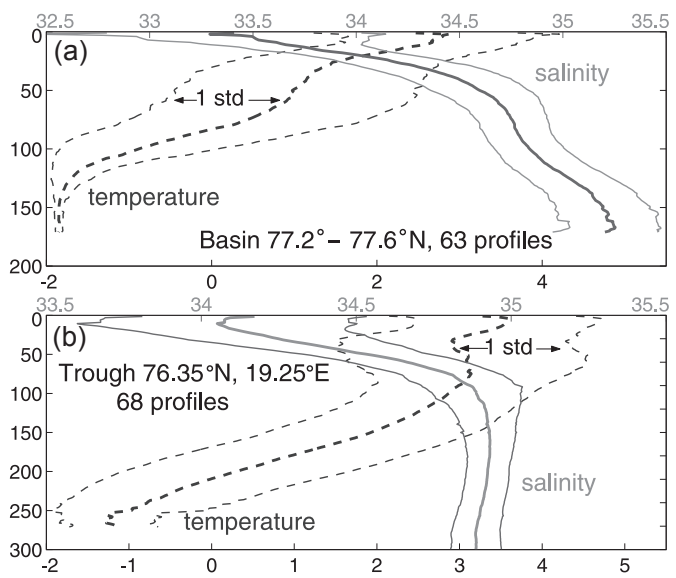

Fig. 5. Ranges of temperature and salinity profiles 1980-2000 around (a) site A and (b) site B.

by Midttun (1985) and Quadfasel et al. (1988). Figure 3 shows summer bottom densities averaged for the period $1950-2000$ on a $10 \mathrm{~km}$ grid. The density field very closely resembles the bottom contours shown in Fig. 4a, where the typical axis of the dense bottom plume's path is indicated. Whereas the plume's width can hardly be estimated from summer data within depressions, the properties can. In particular, the low bottom temperatures in Fig. 5 indicate that the densest waters in the northern reservoir (A) and southern trough (B) still represent the winter water.

Observed ranges of salinity and temperature profiles in the reservoir (A) are shown in Fig. 5a. Generally, at sill depth (ca. $120 \mathrm{~m}$ ) the salinities are $0.1-0.2$ lower than at the bottom $(150-190 \mathrm{~m})$. The restriction of the circulation by the sill tends to conserve the high density of the cold saline winter water below $120 \mathrm{~m}$ until autumn. At the end of winter the bottom water temperature is close to the freezing point: -1.90 to $-1.95^{\circ} \mathrm{C}$. To construct an interannual time series we need, in some years, to use profiles where a warming to $-1.8^{\circ} \mathrm{C}$ has occurred. As, at the $125 \mathrm{~m}$ level, we did not find a salinity change during this first slight warming for several years with temporal summer resolution, this appears to be no restriction. The linear salinity gradient around $125 \mathrm{~m}$ probably helps to preserve the winter salinity at that level during the first mixing phase. Hence, we adopt the $125 \mathrm{~m}$ value during the early summer as representing the maximum winter outflow salinity (SMAX). A measure for the uncertainty is the standard deviation of $125 \mathrm{~m}$ salinities from indi- 

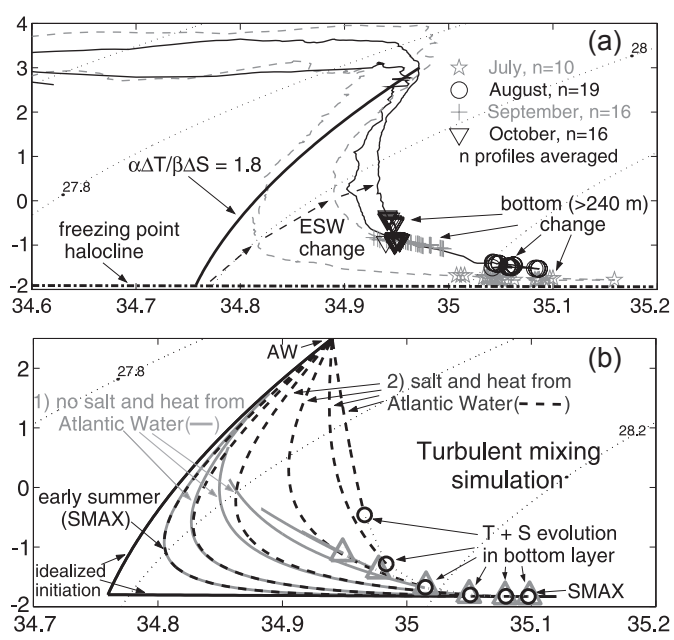

Fig. 6. (a) Average T-S relation change during summer at site B. (b) Vertical mixing simulation of the $\mathrm{T}-\mathrm{S}$ change at site $\mathrm{B}$. The solid grey lines represent case 1 , the dashed lines case 2 . The changing properties of the $40 \mathrm{~m}$ bottom layer are shown as grey triangles for case 1 and circles for case 2 .

vidual years, for which several stations are available within the basin, ranging from 0.01 to 0.08 , with an average of 0.04 .

In the trough (B) the winter outflow is trapped again and often seen until October due to temperatures below $-1^{\circ} \mathrm{C}$ (Fig. 5b). Below $240 \mathrm{~m}$, bathymetry shields the remnants from horizontal mixing, but vertical turbulent mixing during the summer changes their properties. To consider this vertical mixing, a simple diffusion model in $\mathrm{T}-\mathrm{S}$ space is used to reconstruct the early summer property SMAX from late summer observations, making data from different years comparable. We assume an initial late winter $\mathrm{T}-\mathrm{S}$ characteristic of AW, modified during winter through double diffusion along the slope of the Svalbard Bank. Incorporating cold winter water from the bank via salt fingering instabilities it attains a limiting slope of $\alpha \Delta \mathrm{T} / \beta \Delta \mathrm{S}$ ca. 1.8, similar to $\mathrm{T}-\mathrm{S}$ relations described by Rudels et al. (1999) for the Arctic Ocean and Fram Strait. This saltfingering limit and the saltiest water SMAX in the trough are connected in $\mathrm{T}-\mathrm{S}$ space by a halocline at the freezing point, resulting in an idealized almost triangular winter $\mathrm{T}-\mathrm{S}$ relation as initiation, close to the T-S relation from July (Fig. 6a). The principal $\mathrm{T}-\mathrm{S}$ change during summer is characterized by a shift of the salinity minimum, often termed East Spitsbergen Water (ESW), while at the same time the trapped bottom water SMAX

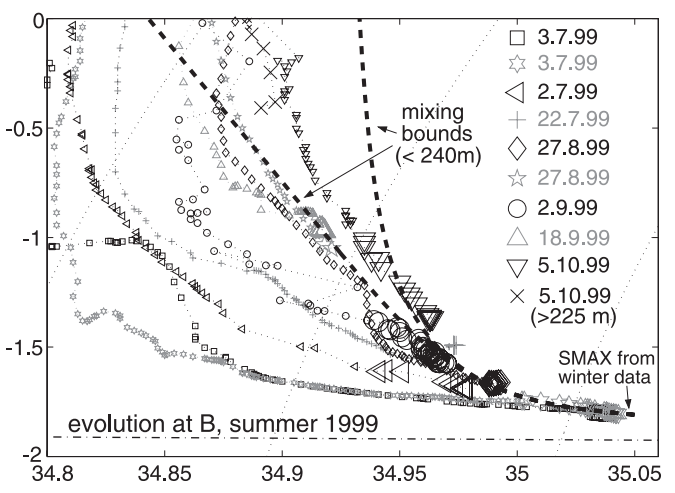

Fig. 7. T-S relation at B for 10 profiles during summer 1999. Large symbols are T-S pairs below $240 \mathrm{~m}$; modelled mixing bounds (connecting traingles and circles in Fig. 6b) are dashed.

warms and freshens (Fig. 6a). The summer T-S change is modelled assuming equal vertical turbulent mixing coefficients for $\mathrm{T}$ and $\mathrm{S}$.

The AW salinity for each simulated summer is depicted from water mass analysis at a fixed temperature of $2.5^{\circ} \mathrm{C}$. From $1950-2000$ these salinties vary between $34.87-35.02$ and in turn set the saltfinger limit curve. By inversion of a vertical turbulent diffusion model the bottom property SMAX of the early summer situation is computed from summer data at different mixing stages. The inverted T-S change depends on the boundary conditions. Two extrema are chosen: (1) the water column below AW is allowed to homogenize itself, conserving heat and salt, or (2) AW properties and depth are fixed, assuming permanent advective renewal of AW with downward transfer of heat and salt. Figure $6 \mathrm{~b}$ shows the modelled change for case 1 and case 2 . The simplified model does not account for horizontal advective exchange of the water below AW (ca. $120 \mathrm{~m}$ ) at site $\mathrm{B}$, hence allowing only for an active upper layer on the order of $100 \mathrm{~m}$.

During 1999 several observations of the dense water in the trough (B) are available from early July to October to test the approach. The evolution of the T-S relation is shown in Fig. 7. The bounds predict the original SMAX within 0.02 , as long as temperatures are below $-1^{\circ} \mathrm{C}$. Only one profile from early July deviates from the diffusion solution by 0.04 in salinity. The inverse calculation of SMAX from all T-S pairs below $240 \mathrm{~m}$ (1 m vertical data spacing) for 1999 results in a standard deviation of 0.021 . For each of 84 individual profiles from 1976 to 2000 (not shown here) the inverted SMAX from $1 \mathrm{~m}$ spaced T-S pairs

Interannual variability of dense shelf water salinities 
below $240 \mathrm{~m}$ is very stable (average $\mathrm{std}=0.011$ ), indicating that $\mathrm{T}-\mathrm{S}$ relations are either homogeneous below $240 \mathrm{~m}$ or evolve along the diffusion bounds. Thus, a single observation, for example at $250 \mathrm{~m}$, allows us to reconstruct SMAX. The uncertainty given by the model bounds is temperature-dependent, increasing rapidly above $-1{ }^{\circ} \mathrm{C}$ and exceeding 0.2 at $0{ }^{\circ} \mathrm{C}$. The applicability of the simple model indicates that the water column at $\mathrm{B}$ is relatively stagnant below $100 \mathrm{~m}$, probably due to a stable eddy in the trough. However, it is also possible that advection of ESW takes place, but that its $\mathrm{T}-\mathrm{S}$ properties in the whole canyon change as being modelled.

The rather independent SMAX reconstructed from the trough (B) data can now be compared to the basin (A) estimates from the $125 \mathrm{~m}$ sill level. Considering the noted uncertainties the estimates agree (Fig. 8). Differences larger than 0.1 (5 of 15 years) may all be attributed to relatively warm water in the trough and a higher reconstruction uncertainty. The average difference $(\mathrm{A}-\mathrm{B})$ in salinity is practically zero (0.001), with a standard deviation of 0.088 . Further support comes from the comparison of the trough (B) salinities with the values from moorings measured by Schauer \& Fahrbach (1999) between sites A and $\mathrm{B}$ - the derived trough (B) values are only slightly lower: -0.04 during winter 1991/92 and -0.05 in $1993 / 94$.

\section{Interannual salinity variability}

The complete derived series of maximum shelf water salinities including data from B before 1980 is shown in Fig. 9a with uncertainty bounds. The data extend back to the years when $250 \mathrm{~m}$ was a standard level during bottle sampling. Observations downstream ( $\mathrm{C}$ in Fig. 4) may include actively entrained AW or ESW, lateral mixing differing from the diffusion scenario. However, where other data were lacking, the years 1964 and 1965 were reconstructed using such observations from early June and applying a linear T-S interpolation with AW and ESW. That approach can be used very early in the summer, but the values are more uncertain.

The interannual range in SMAX exceeds 0.7. A correspondence with the upper layer $(0-50 \mathrm{~m})$ salinity in coastal waters at Sørkapp (Fig. 2) that resembles the westward flowing source water is evident from Fig. 9b. The correlation coefficient

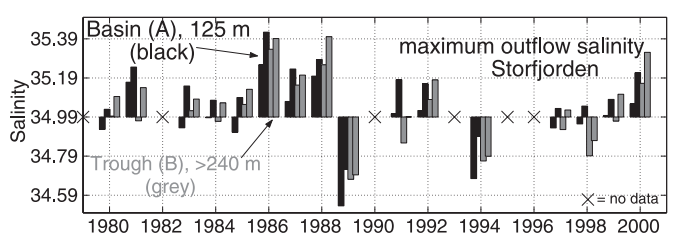

Fig. 8. Maximum outflow salinities derived independently from trough (B) and basin (A) data, uncertainties included.

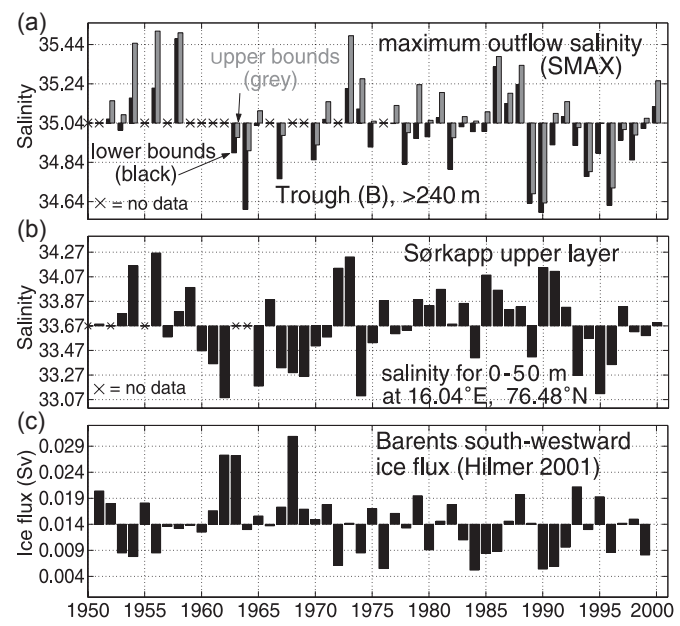

Fig. 9. (a) Upper and lower bounds of maximum outflow salinity, reconstructed from site B data. (b) Upper layer (0-50 m) salinity around Sørkapp. (c) Annual average south-westward Barents Sea ice flux simulated by Hilmer (2001). In (c), units are $\mathrm{Sv}$, defined as $1 \mathrm{~Sv}=10^{6} \mathrm{~m}^{3} / \mathrm{s}$.

of the series is maximal when the surface water salinity leads by one year $(r=0.59)$. As the bottom water formation is a winter process, such preconditioning by the end of the previous summer is reasonable. To evaluate the influence of local ice production I have correlated the maximum salinities with average winter heat fluxes (NovemberApril) computed from passive microwave satellite data (pixels in the basin A) using a thin ice approach (Maus \& Bennet, 2002). For the winters 1988-1999 the correlation was weak and negative $(\mathrm{r}=-0.12)$. It appears that in Storfjorden the upper layer salinity variability dominates over the influence of variable local ice production on the intensity of dense shelf water formation.

To find the origin of the salinity anomalies, time series of upper layer $(0-50 \mathrm{~m})$ salinities were computed for the whole Barents Sea at $25 \mathrm{~km}$ resolution and correlated to SMAX lagged by 1 year. Figure 10 shows a contour map of the 


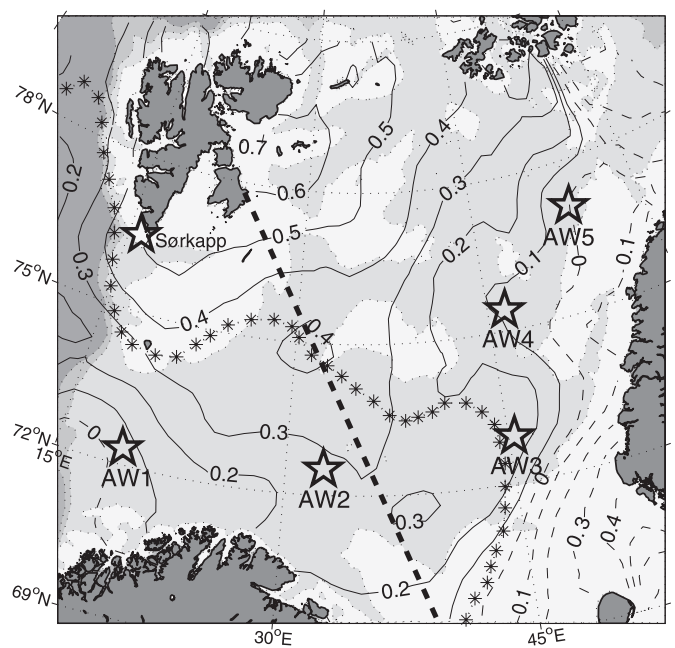

Fig. 10. Correlation coefficient (positive as solid lines) of the dense shelf water salinity from Storfjorden with the upper $(0-50 \mathrm{~m})$ salinity in the Barents Sea one year before.

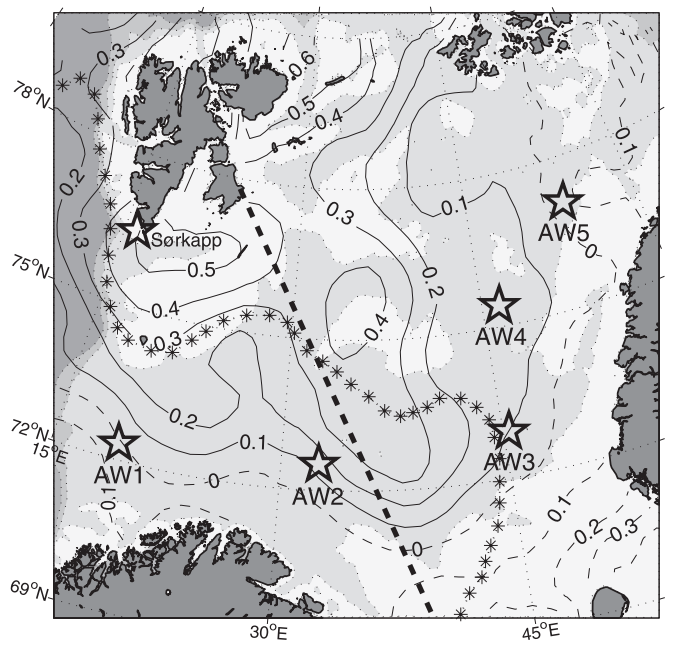

Fig. 11. Correlation coefficient (negative as solid lines) contours of the south-westward annual average ice flux (Hilmer 2001) with upper $(0-50 \mathrm{~m})$ salinities in the Barents Sea.

correlation coefficient smoothed over grid points within $100 \mathrm{~km}$, each value representing typically 10 independent grid series. Largest correlations $(r=0.5-0.7)$ are found east of Svalbard and indicate the source waters for the convection in Storfjorden. A similar map with slightly lower correlations is found without a lag.

What creates the upper salinity variability in the north-west Barents Sea? Figure 9c shows the annual ice volume flux simulated by Hilmer
(2001) in a sea ice model through a section running from the south-eastern tip of Svalbard to the White Sea (Figs. 2, 10). This south-westward ice flux is no direct measurement of the influx of ice from the Arctic Ocean or the Kara Sea, but can be viewed as a proxy for the net ice import to the Barents Sea. The annual mean ice flux is significantly correlated with the surface layer salinity at Sørkapp (Fig. 9b) from the same year $(\mathrm{r}=-0.52)$ and the next year $(r=-0.44)$. The correlation between the dense shelf water salinity and the ice flux is maximal $(r=-0.55)$ when the ice export leads by one year, consistent with the lagged response of dense water to surface salinity anomalies. Further support comes from a contour map of correlation coefficients between Hilmer's annual ice flux and the upper salinities $(0-50 \mathrm{~m})$ over the Barents Sea from the same year (Fig. 11).

\section{Discussion}

By analysing 50 years of data a robust series of maximum shelf water salinity formed within the Svalbard Bank area has been derived. This salinity has a range of 0.7 and is highly correlated $(r=0.5-0.7)$ with the salinity variability in the surface waters of the north-west Barents Sea. A correlation of local polynya ice production based on passive microwave data with the dense shelf water salinity was not found. The upper layer salinity appears to be related to the southwestward ice volume flux simulated by Hilmer (2001). Correlation pattern of dense shelf water salinity, upper layer salinity and ice flux suggest that ice import from the Kara Sea or the Arctic Ocean, as represented by Hilmer's ice flux, converges in the north-west Barents Sea. Subsequent summer melting of the ice would generate interannual salinity anomalies which set the conditions for shelf convection around the Svalbard Bank during the next winter. A rough comparison confirms the relation quantitatively. Taking the Sørkapp upper $50 \mathrm{~m}$ salinity variance of 0.34 as representative for the north-west Barents Sea (area $300000 \mathrm{~km}^{2}$ ), we can estimate a freshwater flux magnitude of $150 \mathrm{~km}^{3}$ per year, comparing well to the variance of $181 \mathrm{~km}^{3}$ in the annual ice volume flux.

During years of high salinities, the dense shelf waters can penetrate the Atlantic layer west of Svalbard, as described for the winter of 1986 by Quadfasel et al. (1988). Under fresh conditions,

Interannual variability of dense shelf water salinities 


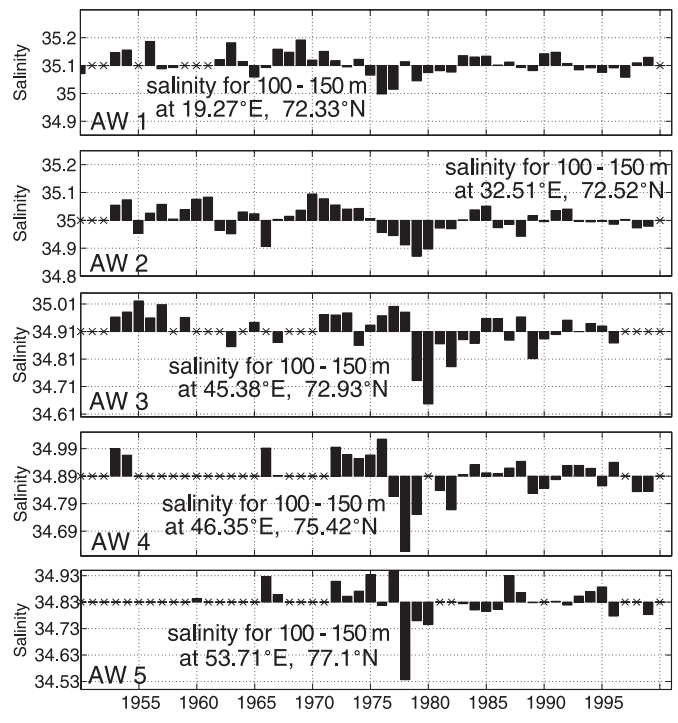

Fig. 12. Average (100-150 m) salinities along the main Atlantic throughflow AW1 to AW5 to the Arctic Ocean; note the same salinity scaling but different upper/lower limits.

deep water formation in the Svalbard Bank region stops, and the less dense water probably interacts with the upper 100-400 m of the West Spitsbergen Current (e.g. Blindheim 1989). To consider the influence of this prominent salinity variability on the GIN Sea we need to compare it to the amount of ice the latter receives from the Arctic Ocean via Fram Strait. For 1950-1999 Hilmer (2001) computed an average annual sea ice flux through Fram Strait of $2630 \mathrm{~km}^{3}$, roughly 5-6 times as large as the average Barents Sea ice flux of $444 \mathrm{~km}^{3}$. However, the largest anomalies of the Barents ice flux are $500 \mathrm{~km}^{3} /$ year compared to $1300 \mathrm{~km}^{3} /$ year for Fram Strait. Of particular interest is the two-year peak in 1962/63 (Fig. 9c) with a total freshwater flux of $900 \mathrm{~km}^{3}$ which initiated the period of low surface and dense water salinities during the 1960s in the Svalbard Bank area (Fig. 9a, b). If part of this freshwater signal is incorporated into the recirculation of modified AW in Fram Strait, it may propagate southwards with the East Greenland Current, eventually turning eastward again and joining the GIN Sea subgyres. The striking drop of the upper layer salinity in Icelandic waters in 1965 (Malmberg et al. 1994), at a time when the Fram Strait ice export was rather small, suggests a possible impact of the ice flux event during 1962/63 on hydrographic and ice conditions in the Iceland Sea $2-3$ years later. As Hilmer (2001) stressed, in the year 1968 the large Fram Strait ice flux anomaly of $1300 \mathrm{~km}^{3}$ was amplified by another $500 \mathrm{~km}^{3}$ anomaly in the Barents Sea ice flux. Hence, the extreme ice flux and freshening of the north-west Barents Sea in 1962/63 and 1968 have to be considered as having preconditioned and created the 1968 Great Salinity Anomaly (GSA), an anomalous export of roughly $2300 \mathrm{~km}^{3}$ of freshwater via the EGC to the North Atlantic (Dickson et al. 1988).

Despite the agreement of interannual variability, the ice flux shows no positive trend and cannot account for the long term decrease in the dense shelf water salinity, especially the very low values during the 1990s (Fig. 9). A different explanation may be found considering the AW inflow from the GIN Sea to the Barents Sea. It took about 7-8 years from 1968 until the GSA returned from the North Atlantic to the GIN Sea (Dickson et al. 1988; Blindheim et al. 2000) and advectively affected the southern Barents Sea at deeper levels. Figure 12 shows the GSA's appearance along the main throughflow path of AW to the Arctic Ocean (AW1 to AW5 in Fig. 2). Between $100-150 \mathrm{~m}$ the salinity anomaly arrived at AW1 in 1976/77. Its evidence at AW4 and AW5 in 1978 indicates a fast, direct passage of AW towards the north-east, compared to a slower flow along AW2 and AW3 in the south-east Barents Sea, where the GSA peaked in 1979. The GSA was enhanced during its passage through the Barents Sea, and the time series AW4 and AW5 indicate a prolonged anomaly in the inflow to the Arctic Ocean from 1978 to 1982 . Since then the salinity has apparently not recovered, and the AW throughflow has remained about 0.05 below that of the 1950s-60s. This still does not explain the typically 0.15 lower SMAX since 1989 (Fig. 9a).

While the freshening of the GIN Sea since the GSA return in 1975/76 (Blindheim et al. 2000; Alekseev et al. 2001) was transferred via the AW inflow to the north-east Barents Sea and likely the Arctic Ocean, what may have sustained this freshening beyond the GSA return? Blindheim et al. (2000) proposed that an increasing influence of Arctic Waters from the East Icelandic Current has freshened the Norwegian Atlantic Current (see Fig. 1), whereas Dickson et al. (2000) suggested enhanced precipitation and the ice export from the Arctic through Fram Strait. We can supplement these hypothesis with a note on the particularly large winter ice extent retreat in the Barents Sea during the early 1990s (Vinje 2001), 
which has been attributed to an increase-also atmospherically driven - in the oceanic heat content of the Barents Sea (Dickson et al. 2000; Vinje 2001). The present data set localizes the largest freshening in the northern Barents Sea (not shown). These considerations suggest that local ice melt due to anomalous oceanic heat content is the most likely cause for the low dense shelf water salinities during the 1990s.

In summary, the interpretation of three striking salinity signals in the Barents Sea indicates three different causalities. During the 1960s, dense water formation in the north-west Barents Sea was reduced by excessive ice import. In the north-east Barents Sea the strongest signal is identified as the advective GSA return from 1978-1982. The origin of a strong freshening of dense shelf waters in the north-west Barents Sea during the 1990s is most consistent with the decrease in average ice extent due to increased oceanic heat content (Dickson et al. 2000; Vinje 2001). The considerable decadal salinity variability generated in the Barents Sea by different processes is transferred to a variety of depths within the GIN Sea and the Arctic Ocean. Considering the water sphere below $500 \mathrm{~m}$ and its ventilation from the Barents Sea (Anderson et al. 1999; Goldner 1999) it is worth noting that both the lower salinities of a brine-induced dense water source in the north-west Barents Sea and of the throughflow branch to the Arctic Ocean during the past two decades are consistent with reported freshening in the densest fractions of the deep overflows to the North Atlantic (Dickson et al. 2002). The discussion of anomalies presented in this study emphasizes the large variability in the Barents Sea and stresses that different mechanisms may have contributed to this freshening.

Acknowledgements.-The Institute of Marine Research, Bergen, kindly provided the hydrographic database; I thank E. Svendsen and S. Lygren. I am grateful to C. Oelke (ACSYS) for his support with the BarKode data, and to J. Karstensen and two reviewers for their comments on this paper.

\section{References}

Alekseev, G. V., Johannessen, O. M., Korablev, A. A., Ivanov, V. V. \& Kovalevsky, D. 2001: Interannual variability in water masses in the Greenland Sea and adjacent areas. Polar Res. 20, 201-208.

Anderson, L. G., Jones, E. P. \& Rudels, B. 1999: Ventilation of the Arctic Ocean estimated by a plume entrainment model. J. Geophys. Res. 104(C6), 13423-13429.
Blindheim, J. 1989: Cascading of Barents Sea bottom water into the Norwegian Sea. Rapp. P.-v. Reun. Cons. Int. Explor. Mer 188, 49-58.

Blindheim, J., Borovkov, V., Hansen, B., Malmberg, S. Å., Turrell, W. R. \& Østerhus, S. 2000: Upper layer cooling and freshening in the Norwegian Sea in relation to atmospheric forcing. Deep Sea Res. I 47, 655-680.

Dickson, R., Meincke, J., Malmberg, S.-Å. \& Lee, A. J. 1988: The "Great Salinity Anomaly" in the northern North Atlantic 1968-1982. Progr. Oceanogr. 20, 103-151.

Dickson, R., Osborn, T. J., Hurrell, J. W., Meincke, J., Blindheim, J., Ådlandsvik, B., Vinje, T., Alekseev, G. \& Maslowski, W. 2000: The Arctic Ocean response to the North Atlantic Oscillation. J. Clim. 13, 2671-2696.

Dickson, R., Yashayaev, I., Meincke, J., Turrell, T. J., Dye, S. \& Holfort, J. 2002: Rapid freshening of the deep North Atlantic Ocean over the past four decades. Nature 416, 832-836.

Goldner, D. 1999: Steady models of Arctic shelf-basin exchange. J. Geophys. Res. 104(C12), 29733-29755.

Golubev, V. A. \& Zuyev, A. N. 1999: Barents and Kara seas Oceanographic Data Base (BarKode). ACSYS IACPO Report 5. C. Oelke (ed.). Tromsø, Norway: World Climate Research Programme, Arctic Climate System Study.

Haarpaintner, J., Haugan, P. M. \& Gascard, J.-C. 2001: Interannual variability of the Storfjorden ice cover and ice production observed by ERS-2 SAR. Ann. Glaciol. 33, 430-436.

Hilmer, M. 2001: A model study of Arctic sea ice variability. $\mathrm{PhD}$ thesis, Institut für Meereskunde, University of Kiel.

Loeng, H. 1991: Features of physical oceanographic conditions of the Barents Sea. Polar Res. 10, 5-18.

Malmberg, S.-Å., Valdimarsson, H. \& Mortensen, J. 1994: Long time series in Icelandic waters. ICES Mar. Sci. Symp. 1994, S:8.

Maus, S. 1995: Bodenwasserformation im Storfjord. (Bottom water formation in Storfjorden.) Dipl. thesis, Institute of Oceanography, Hamburg.

Maus, S. \& Bennet, C. 2002: Estimating ice thickness in polynyas from passive microwave data. In: Abstracts: Workshop Sea-Ice Extent and the Global Climate System (1517 April 2002) and Mini-Conference Long-Term Variability of the Barents Sea Region (18-19 April 2002). Pp. 26-27. International ACSYS/CliC Project Office of the World Climate Research Programme, Office of Naval Research International Field Office, Météo-France. Available on the internet at http://acsys.npolar.no/meetings/toulouse/ abstracts12.pdf.

Midttun, L. 1985: Formation of dense bottom water in the Barents Sea. Deep Sea Res. 32, 1233-1241.

Østerhus, S. \& Gammelsrød, T. 1999: The abyss of the Nordic seas is warming. J. Clim. 12, 3297-3302.

Quadfasel, D., Rudels, B. \& Kurz, K. 1988: Outflow of dense water from a Svalbard fjord into the Fram Strait. Deep Sea Res. 35, 1143-1150.

Rudels, B., Björk, G., Muench, R. D. \& Schauer, U. 1999: Double-diffusive layering in the Eurasian Basin of the Arctic Ocean. J. Mar. Syst. 21, 3-27.

Schauer, U. 1995: The release of brine-enriched shelf water from Storfjord into the Norwegian Sea. J. Geophys. Res. 100(C8), 16015-16028.

Schauer, U. \& Fahrbach, E. 1999: A dense bottom water plume in the western Barents Sea: downstream modification and interannual variability. Deep Sea Res. I 46, 2095-2108.

Vinje, T. 2001: Anomalies and trends of sea-ice extent and atmospheric circulation in the Nordic seas during the period 1864-1998. J. Clim. 14, 255-267.

Interannual variability of dense shelf water salinities 